rzaniu dawnych, nawet uświęconych wielowiekową tradycją terminów i pojęć. Przeciwnie powinno się ono wyrazić w poszukiwaniu nowych pełniejszych rozwiązań, które odpowiadają dzisiejszemu, poszerzonemu ujęciu natchnienia i złożonemu obrazowi literackiemu Biblii. Ta sama moc i to same działanie Boga, które leży u podstaw Bliblii jako "słowa prawdziwego", sprawia, że jest ono zarazem słowem $\dot{z} y$ wym i skutecznym ( $\mathrm{Hbr} 4,12)$. Wszystkie trzy momenty powinny zostać uwypuklone jako trzy różne aspekty jednego i tego samego charyzmatycznego działania Ducha Sw. W tym względzie otwiera się szczególnie wdzięczne pole badań dla teologów i niewiele oznak wskazuje na to, byśmy już dzisiaj byli bliscy takiego rozwiązania problemu, który można by nazwać chociażby tylko zadawalającym.

Pelplin

KS. HENRYK MUSZYÑSKI

\author{
Ks. Tomasz Jelonek
}

\title{
LINGWISTYKA MATEMATYCZNA JAKO NARZĘDZIE BADANIA PISMA ŚWIĘTEGO
}

Celem niniejszego komunikatu jest przedstawienie kilku uwag związanych z zasygnalizowanym tematem. Nie podejmujemy się bowiem przedstawić całościowej i systematycznie ujętej problematyki, co wymagałaby o wiele szerszych ram, a przede wszystkim powinno być ilustrowane przykładami, na które przyjdzie nam jeszcze poczekać.

Wszyscy doskonale wiemy, że Pismo Swięte zawiera tajemnice Słowa Bożego w ludzkiej szacie literackiej. Właśnie ze względu na tę szatę trzeba dla zbadania właściwej myśli objawionej sięgać do pełnego arsenału metod badawiczych stosowanych we współczesnej nauce. Do nich zaliczają się także metody lingwistyki matematyeznej. Jest ona nauką, która wykorzystuje do badań językoznawczych osiągnięcia takich dziedzin matematycznych, jak logika, teoria zbiorów i statystyka.

Wprowadzając metody matematyczne lingwistyka matematyczna stosuje ujęcia ilościowe. Jej rozwój zostal spowodowany rozwojem maszyn liczących. Maszyny te bowiem z jednej strony dają możliwość szyblkiego operowania dużą ilością danych, pozwalając w krótkim czasie dokonywać systematyzacji czy katalogowania występujących zjawisk językowych, słów, form gramatycznych czy wzajemnych między nimi relacji. $Z$ drugiej strony maszyny liczące wymagają stworzenia sztucznych języków służących do porozumienia się czlowieka $\mathrm{z}$ maszyną lub będących systemem infarmatycznym wewnątrz maszyny. W twarzeniu i udoskonalaniu sztucznych języków wykorzystuje się osiągnięcia lingwistyki matematycznej.

Lingwistyka matematyczna zależnie od stosowanego aparatu matematycznego dzieli się na językoznawstwo algebraiczne, wykorzystujące aparat logiki i teorii zbiorów oraz językoznawstwo statystyczne ujmujące prawidłowości statystyczne w lingwistyce. 
Pierwszy z kierunków prowadzi do matematycznego opracowania gramatyk i do konstrukcji języków sztucznych, a następnym etapem tych badań jest teoria i praktyka tłumaczeń maszynowych. Lingwistyka statystyczna stara się w gąszczu faktów indywidualnych odnaleźć stałe tendencje i prawidłowości. Te ogólne prawidłowości statystyczne na terenie lingwistyki wynikają z psychologicznej struktury natury ludzkiej odbijającej się w tym wypadku w słowie przez człowieka napisanym. Na tle tych prawidłowości bada się indywidualny styl jako swoiste odchylenie od normy. Zajmuje się tym kierunek badań zwany stylostatystyką.

Nie wchodząc już głębiej $\mathrm{w}$ problematyke lingwistyki matematycznej jako takiej, rozpatrzmy krótko możliwości zastosowania jej metod do badania Pisma Swiętego. Przechodząc do tego zagadnienia zauważmy na początku, że odnośnie tekstu Pisma Świętego dokonano już w okresie poprzedzającym komputeryzację wiele zestawień inwentaryzacyjnych, które obecnie $\mathrm{w}$ odniesieniu do innych działów literatury czy poszczególnych dzieł literackich uzyskuje się dzięki pracy maszyn liczących. Nie musimy zatem w ten sposób opracowywać konkordancji, zestawów słownikowych czy statystycznych. Te wstępne kroki, służące dalszej analizie, na terenie biblistyki mamy za sobą.

Dotychczasowe osiągnięcia $\mathrm{w}$ dziedzinie maszynowych tłumaczeń tekstów różnojęzycznych nie doprowadziły jeszcze do takich wyników, które mogłyby sprostać wymogom przekładu biblijnego. Pozostaje więc wykorzystanie lingwistyki statystycznej, a w szczególności stylostatystyki.

Dzięki niej możemy ilościowo ując bogactwo słownictwa, stopień jego koncentracji, możemy śledzić indywidualne predyspozycje autorów, a także ich, może nawet nie $w$ pełni uświadomione tendencje. Takie badania pomagaja $\mathrm{w}$ rozstrzygnięciu kwestii autorstwa i chronologii pism zwlaszcza. jednego i tego samego autora. Ilościowe ujęcie zagadnienia stylu może pomóc $\mathrm{w}$ odczytaniu zamierzeń autora, wiemy zaś doskonale, że co zamierzał przekazać autor natchniony, to chce nam przekazać Duch Swięty.

Nie wyobrażamy sobie, aby badania lingwistyczne matematyczne w decydujący sposób pomogły nam w rozwiązywaniu kwestii biblijnych. Dalecy jesteśmy od mitycznego kultu matematyki i jej metod. Nie są one, wbrew przejawiającym się czasem tu i ówdzie poglądom, antidotum na wszelkie kłopoty. Matematyka może pomagać, ale nie zrobi wszystkiego. Bałwochwalcza wiara w jej nieograniczone możliwości to szkodliwy mit dwudziestego wieku, słusznie już zanikający.

Zdajemy sobie sprawe z ograniczonych możliwości zastosowań i ograniczonych korzyści, jakiē możemy osiągnąć, aby jednak sprostać postulatowi wykorzystania wszelkich możliwych środków dla lepszego poznania ludzkiej szaty literackiej, w jaka zostało zamknięte Słowo Boga, należy $i$ ten dział naukowych osiągnięć uwzględniać $w$ badaniach biblijnych. 